follows. The mean fluorescent intensity (MFI) was calculated for each protein using WinMDI software (J Trotter, Scripps Research Institute, USA) and these values were then converted to molecules of equivalent soluble fluorochrome (MESF) using a calibration curve to standardize the data. The calibration curve was constructed by operating the flow cytometer under identical conditions and monitoring a mixture of beads labelled with known amounts of fluorochrome. In this way, day-to-day variation in fluorescence detection are controlled for, and, in addition, differences in fluorescent intensity between FITC and PE can be normalized. Obviously we would be willing for Williamson et al to have a copy of the raw data derived from these experiments and would also refer them to our publication in the British Journal of Haematology (1996).

The Bcl-2 and Bax protein expression presented in this paper relate to the total population of cells, regardless of their status in terms of response to apoptotic signals, i.e. no attempt was made to gate viable and non-viable cells. However, we agree that it is of interest to measure $\mathrm{Bcl}-2$ and Bax protein levels both before and after exposure to drug. This indeed is the subject of our latest publication in Leukemia \& Lymphoma (1998). Briefly, our results indicate that $\mathrm{Bcl}-2$ and $\mathrm{Bax}$ protein levels are significantly different in those cells that resist apoptosis when compared with those that do not, and this difference is particularly pronounced in terms of Bax protein expression.

In the Annexin $\mathrm{V}$ positivity experiments we used Annexin $\mathrm{V}$ as a measure of apoptosis. It is true that Annexin $\mathrm{V}$ is capable of labelling very early-stage apoptotic cells that have not yet undergone morphological changes. However, we would point out that in these experiments we labelled our cells with Annexin V after incubation with drug for $48 \mathrm{~h}$ and most of the cells that were undergoing apoptosis were in fact late-stage apoptotic cells that were easily identified morphologically by membrane blebbing, chromatin condensation and general cellular shrinkage. Recent data from our laboratory have confirmed that morphological evidence of apoptosis can be seen as early as $16 \mathrm{~h}$ after drug exposure but is much more marked after $24 \mathrm{~h}$ (unpublished).

\section{P Bentley, C Pepper and T Hoy}

Llandough Hospital, Penlan Rd, Penarth CF $642 X X, U K$

\section{REFERENCES}

Korsmeyer SJ, Shutter JR, Veis DJ, Merry DE and Oltvai ZN (1993) bcl-2/bax: a rheostat that regulates an anti-oxidant pathway and cell death. Sem Cancer Biol 4: 327-332

Pepper C, Bentley P and Hoy T (1996) Regulation of clinical chemoresistance by bcl-2 and bax oncoproteins in B-cell chronic lymphocytic leukaemia. $\mathrm{Br} \mathrm{J}$ Haematol 95: 513-517

Pepper C, Hoy T and Bentley P (1998) Elevated Bcl-2/Bax are a consistent feature of apoptosis resistance in B-cell chronic lymphocytic leukaemia and are correlated with in vitro chemoresistance. Leuk Lymphoma 28: 355-361

Thomas A, El Rouby S, Reed JC, Krajewski S, Silber R, Potmesil M and Newcomb EW (1996) Drug-induced apoptosis in B-cell chronic lymphocytic leukemia: relationship between $\mathrm{p} 53$ gene mutation and bcl-2/bax proteins in drug resistance. Oncogene 12: 1055-1062

\title{
Insulin-like growth factor 1 in relation to prostate cancer and benign prostatic hyperplasia
}

Sir,

We were interested to read the paper by Mantzoros et al (1997) claiming that serum insulin-like growth factor 1 (IGF-1) levels were elevated in prostate cancer patients and suggesting that serum IGF-1 may represent an independent risk factor for this disease. This is in marked contrast to our data demonstrating that serum IGF-1 and IGF-2 levels were not different in patients with prostate cancer relative to age-matched controls (Cohen et al, 1993). Similarly, Ho and Baxter (1997) found normal IGF-1 levels in the sera of patients with prostate cancer. The IGFs circulate complexed to a family of proteins known as the IGF-binding proteins (IGFBPs), as reviewed by Daughaday et al (1986). Apparently, unknown to these authors, IGFBPs have been shown to interfere with radioimmunoassays (RIAs) of the IGFs as a result of their ability to bind to the labelled IGF trace and to artifactually elevate the readings of IGF levels, as reviewed by Rosenfeld and Gargosky (1996). While various methods have been used to attempt to remove the IGFBPs from the IGFs before assay, only techniques involving acidification followed by chromatography have been demonstrated by Bang et al (1991) to successfully perform this separation. RIAs, such as the Nichols kit used by Mantzoros et al (1997), use an ethanol extraction method which, while able to remove most of the IGFBP-3 found as the $150-\mathrm{kDa}$ complex of the IGFs, are completely ineffectual in removing other IGFBPs in serum including IGFBP-2 and IGFBP-4, as shown by
Frey et al (1994). In our report (Cohen et al, 1993), we have shown a two- to threefold elevation in IGFBP-2 levels in the sera of patients with prostate cancer as assayed by both RIA and Western ligand blotting. We have since verified that observation on a second cohort of patients and, in addition, we have demonstrated a more moderate elevation of IGFBP-2 levels in the sera of patients with benign prostatic hyperplasia. We have also recently found a twofold elevation in the serum levels of IGFBP-4 in the sera of prostate cancer patients. Our findings of elevated IGFBP-2 in prostate cancer patients have also been replicated by Kanety et al (1993) and Ho and Baxter (1997). As IGFBP-2 and IGFBP-4 are not removed by the ethanol extraction method used by Mantzoros et al (1997), we believe that their patients actually had normal serum IGF-1 levels, but elevated serum IGFBP-2 and IGFBP-4 levels, leading to an artifactual elevation in the IGF-1 RIA reading. This situation is similar to a report in the New England Journal of Medicine by Pintor et al (1989), allegedly discovering a child with phenotypic Laron dwarfism but with normal IGF-1 levels (which are dramatically reduced in that condition). Those authors used the exact same Nichols IGF-1 RIA kit to measure IGF-1 levels in the serum of their subject as Mantzoros et al (1997) did in their paper. Alerted to the possibility of an artifact by a letter to the editor from Laron and Silbergeld (1989), the authors re-assayed their child's serum IGF-1 with an acid-chromatography technique and discovered it to be undetectable, leading them to issue a retraction of their 
report (Pintor et al, 1990). The editor of the New England Journal of Medicine at the time wrote an editorial to accompany that retraction entitled 'An error corrected, a conclusion withdrawn, and a lesson learned' (Relman, 1990). Unfortunately, this artifactprone assay remains in wide use. While many data exist in support of a role for the IGF system in the pathogenesis of prostate cancer, it is the autocrine-paracrine involvement of IGFs and IGFBPs that is commonly implicated, as reviewed by Peehl et al (1996). However, measurements of IGF-1 in two previous studies using valid methodologies (Cohen et al, 1993; Ho and Baxter, 1997), demonstrated normal serum levels, indicating that there is no relationship between circulating IGF-1 levels and the prevalence of prostate cancer. We would therefore like to encourage Mantzoros et al (1997) to re-assay their patients' sera in an IGF-1 assay, which can be demonstrated to be free of IGFBP interference; otherwise, their conclusions may not be valid.

\section{$P$ Cohen', D M Peehl' and R Rosenfeld.}

${ }^{\prime}$ Children's Hospital of Philadelphia, University of Pennsylvania, Philadelphia, PA, USA; 'Department of Urology; Stanford University Medical Center, Stanford, CA, USA, 'Department of Pediatrics, Oregon Health Sciences University, Portland, ON, USA

\section{REFERENCES}

Bang P, Eriksson U. Sara V. Wivall I-L and Hall K (1991) Comparison of acid-ethanol extraction and acid gel filtration prior to IGF-I and IGF-II radioimmunoassays: improvement of determinations in acid ethanol extracts by the use of truncated IGF-I as radioligand. Acta Endocrinol 124: 620-629
Cohen P. Peehl DM, Stamey TA. Wilson K. Clemmons DR and Rosenfeld RG (1993) Elevated levels of insulin-like growth factor binding protein-2 in the serum of prostate cancer patients. J Clin Endocrinol Metab 76: 830-835

Daughaday WH, Kapadia M, Mariz IK (1986) Serum somatomedin binding proteins: physiologic significance and interference in radioligand assay. J Lab Clin Med 109: 335-363

Frey RS. Hathaway MR and Dayton WR (1994) Comparison of the effectiveness of various procedures for reducing or eliminating insulin-like growth factorbinding protein interference with insulin-like growth factor-I radioimmunoassays on porcine sera. $J$ Endocrinol 140: 229-237

Ho PJ and Baxter RC (1997) Insulin-like growth factor-binding protein-2 in patients with prostate carcinoma and benign prostatic hyperplasia. Clin Endocrinol 46: 333-342

Kanety H, Madjar Y, Dagan Y, Levi J, Papa MZ, Pariente C. Goldwasser B and Karasik A (1993) Serum insulin-like growth factor-binding protein-2 (IGFBP-2) is increased and IGFBP-3 is decreased in patients with prostate cancer: correlation with serum prostate-specific antigen. J Clin Endocrinol Metab 77: 229-233

Laron Z and Silbergeld A (1989) A child with phenotypic Laron dwarfism and normal somatomedin levels (letter). $N$ Engl J Med 320: 1698-1699

Mantzoros CS, Tzonou A, Signorello LB, Stampfer A. Trichopoulos D and Adami $\mathrm{HO}$ (1997) Insulin-like growth factor 1 in relation to prostate cancer and benign prostatic hyperplasia. Br J Cancer 76: 1115-1118

Peehl DM. Cohen P and Rosenfeld RG (1996) The role of IGFs in prostate biology. $J$ Androl 17: 2-4

Pintor C. Loche S. Cella SG. Muller EE and Baumann G (1989) A child with phenotypic Laron dwarfism and normal somatomedin levels. $N$ Engl J Med 320: $376-379$

Pintor C. Loche S. Cella SG. Muller EE and Baumann G (1990) Correction and withdrawal of conclusion - a child with phenotypic Laron dwarfism and normal somatomedin levels. $N$ Engl J Med 323: 1485

Relman A (1990) An error corrected, a conclusion withdrawn, and a lesson learned. $N$ Engl J Med 323: 1485

Rosenfeld RG and Gargosky SE (1996) Assays for insulin-like growth factors and their binding proteins: practicalities and pitfalls. $J$ Pediatr 128: $52 \mathrm{~S}-57 \mathrm{~S}$

\section{Insulin-like growth factor 1 in relation to prostate cancer and benign prostatic hyperplasia - reply to the letter from Cohen, Peehl and Rosenfeld}

Sir,

We thank Dr Cohen and colleagues for their interest in our paper. They may or may not be correct in their assertion that the laboratory procedure that we have used to measure insulin-like growth factor 1 (IGF-1) has reduced specificity, notwithstanding the manufacturers' claim of no interference. What they fail to realize, however, is that their own study (Cohen et al, 1993) is actually suggestive of a positive association between IGF-1 and prostate cancer. Indeed, had their study been as large as ours ( 51 cases and 52 controls), the difference between mean IGF-1 levels of their cases and controls would have been marginally significant $(P=0.06)$. They have also made a mistake in their indication of the 'standard error' of the mean IGF-1 value, when, in reality, this must have been the standard deviation - otherwise the standard deviation of IGF-1 among their cases would have been much higher than their mean value! There is a lesson here: lack of statistical significance is frequently due to limited statistical power and should never be the basis for a confident assertion of no association. The other study that Cohen and colleagues refer to (Ho and Baxter, 1997 ) is even smaller than their own, with only seven controls.
Cohen and colleagues' claim also implies that a qualitatively similar phenomenon would create an artificial positive association between IGF-1 and benign prostatic hyperplasia (BPH), even though in our study there was absolutely no relationship between IGF-1 and BPH after adjusting for confounding variables (Table 4 in Mantzoros et al, 1997). If they are still worried, however, they could also look to the findings of a new study recently published in Science (Chan et al, 1998). Using a different assay, this study has confirmed our findings almost to the decimal point.

\section{CS Mantzoros ${ }^{1,2}$, LB Signorello ${ }^{I}$ and D Trichopoulos ${ }^{\prime}$}

'Department of Epidemiology and Harvard Center for Cancer Prevention, Harvard School of Public Health, Boston, MA, USA; ${ }^{2}$ Division of Endocrinology, Beth Israel Deaconess Medical Center, Harvard Medical School, Boston, MA, USA

\section{REFERENCES}

Chan JM. Stampfer MJ, Giovannucci E. Gann P, Ma J. Wilkinson P. Hennekens CH and Pollak M (1998) Plasma insulin-like growth factor-I and prostate cancer risk: a prospective study. Science 279: 563-566 